\title{
Mosalaki: Central Point of Traditional Leadership System in Lio Ethnic Group in Sikka District, East Nusa Tenggara
}

\author{
Suswandari ${ }^{1}$, Sri Astuti ${ }^{2}$ \\ ${ }^{1)}$ History Education Study Program, FKIP UHAMKA \\ ${ }^{2)}$ Economic Education Study Program. FKIP UHAMKA \\ ${ }^{1}$ suswandari@uhamka.ac.id \\ ªstuti@uhamka.ac.id
}

\begin{abstract}
Indonesia's ethnic diversity has become a world-recognized identity. There are more than 750 ethnic groups throughout Indonesia from Sabang to Merauke. Every ethnic group has its character and is also an image of a proud cultural system. The Lio ethnic group is one of the ethnic groups on the island of Flores with their traditional ties and values of local wisdom that enrich Indonesia's diversity. One of its values include the local leadership known as Mosalaki. In Sikka Regency, the status of a Mosalaki in the Lio ethnic group is still the central point of the social structure. The Mosalaki are prominent figures in terms of their origins, authority and charisma that are not shared by society in general. In various traditional ceremonial procedures, the Mosalaki have an essential role to play, such as deciding the planting season, land management procedures, marriage procedures, and procedures for preserving and ensuring the wellbeing of people, contact behaviour, the belief system embraced even in the realm of modern politics today. This research was conducted using a qualitative approach as developed by Spradley. The results of the study describe that the role of a Mosalaki is still the focal point of all activities in the Lio ethnic, especially in the modern world today. In Sikka Regency, the Mosalaki is an important part of development efforts.
\end{abstract}

Keywords: Mosalaki, Lio Ethnic, Sikka Regency.

\section{INTRODUCTION}

Sikka regency has a diverse ethnicity system in East Nusa Tenggara (NTT) with traditional/distinctive cultural colours that are still retained and continued to this day. The residents of Sikka Regency also consist of different cultural, linguistic, and ethnic groups, like other areas in NTT [1]. Therefore, many claims that
Sikka Regency is a miniature of Indonesia. Many parties acknowledge that Indonesia is a multicultural country [2] which is characterized by a harmonious life in differences in customs and cultures. Some of the social tensions that have arisen in recent years have mostly been triggered by external forces that no longer maintain the local wisdom owned by each ethnic group in Indonesia. The map of the region of Sikka Regency is as shown below. 


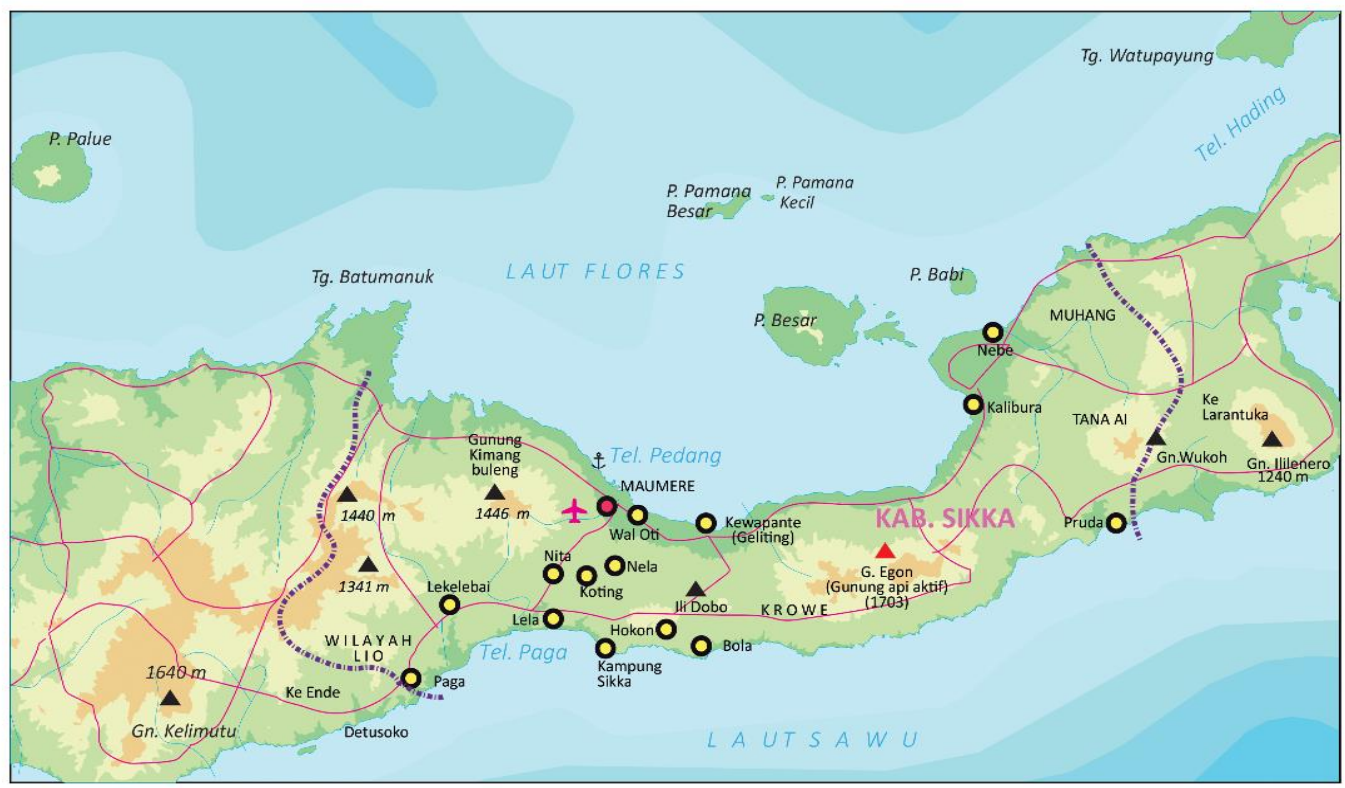

Figure 1. Sikka Region

There are five major ethnic groups in Sikka Regency, namely Sikka Krowe, Lio, Tana Ai, Palue and Tidung [3]. Each ethnic group has a different geographical area and various forms of customary provisions that are different from one another. The Lio ethnic group is the second largest ethnic goup, after the Sikka Krowe ethnic group in Sikka Regency [4]. The Lio ethnic live in the western part of the Sikka Regency to Ende Regency. In some historical records, the Lio ethnic originated from Ende Regency. The residential area of the Lio people is currently divided into several sub-districts, such as in Ndona, Detusoko, Wolowaru, and Mourole, in Ende District. The word LIO is defined as Lise Ila Obo. The word Lise means a torchlight [5]. Some sources even explain that the Lio ethnic group is the oldest ethnic group on the island of Flores. The island of Flores currently consists of eight districts, namely Manggarai Regency, West Manggarai Regency, East Manggarai Regency, Ngada Regency, Nagekeo Regency, Ende Regency, Sikka Regency, East Flores Regency (Flotim). The Lio ethnic group has its language called Lio Language. Lio women's traditional clothing is called Lawo Lambu, and men's clothing consists of Regi, Semba, and Lesu. The Ga'i or Gawi is a typical dance for the Lio people which is accompanied by music from a coconut shell musical instrument.

The Lio ethnic in Sikka Regency lives in the West, for example, in Paga District, Tanawawo District and Mego District. The Lio sub-ethnic group consists of three sub-ethnic groups. (1) Mbengu in Paga District consists of the customary areas of Wolowiro, Wesopeto, Paga, Masubewa, Wolorega, Mbengu, Lenandarita. (2) $\mathrm{Bu}$ in Tanawawo District consists of the customary areas of North $\mathrm{Bu}$, South $\mathrm{Bu}, \mathrm{Bu}$ Watuweti, Rekangasi, Loketowa Puma. (3) Megonualolo in Mego District consists of the customary areas of Bera, Wololesa, Para Bubu, Liakutu, Naunggara, Dobo. Their distribution area is also in Megowena, Kolisia Village in Pagepanda District, Magepanda, Done, Leroroja. They live in mountainous, rocky, and infertile area [6]. The natural conditions of the Lio ethnic group in Ende District is as described by [6], as follows:

“... keadaan tanah di Lio itu ganas, akibat gunung gemunung dan anak gunung serta bukit-bukit yang tak terjumlahkan. Jurang jurang terjal dan lembah-lembah yang dalam menambah keganasan geografi. Sungai sungai besar berair tetap dan kali kali kering menempuh jalan liar di musim hujan. Sungai sungai besar atau lowo ria bertambah dalam dan berkelok kelok “.

"...because of its numerous mountains and uncountable hills, the geographical situation in Lio is complicated and challenging. There are so many rugged ravines and deep valleys, contributing to their ferocity. In the rainy season, the rivers with great streams of constant water and the dry ones come through into the wild lane. During the rainy 
season, large rivers or lowo ria deepens and curve".

As cited above the environment of the Lio ethnic group in Ende Regency illustrates the extreme natural challenges facing the Lio ethnic group in order to survive. This condition is almost the same state as the ethnic community of Tana $\mathrm{Ai}$ in the East [7]. The Lio Ethnic people, in general, are physically tall and stocky for men. Their livelihood comes from farming in rice fields and gardening which in Lio is called "Kema Uma". The farming and gardening are known as Kema Uma Pare (rice plantation), Kema Uma Ke'o (corn plantation), Kema Uma Muku, Uwi Kaju (banana, cassava plantation). The Kema Uma harvest is sold on the market, and part of that harvest is used for daily food. Before the was rice, the typical food in the Kanganara and Paga traditional areas was ondo (forest sweet potato). However, the today's typical foods of the Lio ethnic group are $u^{\prime} u$ (corn flour), khibi (melinjo chips), filu (cucur cake), are (rice), and moke (palm wine). The Lio ethnic group is a traditional farmer. They live side by side with nature and upholds customary norms in carrying out a life between traditional groups or with other traditional groups [8]. As an agrarian society, the Lio ethnic kinship system is patriarchal, which places the father/male family member as having a significant role in the survival of the family. One of the important characteristics of an agrarian society is the large gap between its dominant and subordinate classes in power, privilege and prestige. Of all pre-industrial societies, an agrarian society is the most stratified society [9]. This situation also affects the customary leadership system called Mosalaki, which is a leardership position and role within the Lio ethnic group.

\section{RESEARCH METHOD}

This research is classified as qualitative research using an ethnographic approach as developed by Spradley [10]. The object of data in this study is Mosalaki ethnic Lio in Paga District, Sikka Regency, which is obtained through participant observation and in-depth interviews which are characteristic of qualitative research [11]. Several essential documents from them also support the data. In this research, the ethnographic approach was chosen because the aim of the study was to explore data on the Lio ethnic group's life activities in the district of Sikka, which is related to the traditional local leadership model in this area. Bogdan and Biklen [12] and Cresswell clarified that qualitative research is supposed to generate detailed, holistic and comprehensive explanations of speech, behaviour, actions, writing, observable words of a person, community, society or certain organizations in specific settings [13]. This research seeks to be able to describe in-depth the local leadership patterns of the Lio ethnic group in their distinctive life, which in modern anthropology are mentioned by Radcliffe and Malinowski as a way of life [14]. Data analysis was carried out using stepwise forward analysis which includes: (1) determining informants, (2) in-depth interviews with informants, (3) compiling ethnographic fieldnotes, (4) asking descriptive questions, (5) analyzing ethnographic interviews, (6) making domain analysis, (7) asking structural questions, (8) making taxonomic analysis, (9) asking contrast questions, (10) making component analysis, (11) finding cultural themes, and (12) writing an ethnography. [10]

\section{RESULTS AND FINDINGS}

\subsection{Position and Role of Mosalaki in the Lio Ethnic Social System}

The discussion about ethnicity is complex [15], including the issue of leadership based on an agreement in the community it leads. JJ Rousseau 's The Du Social Contract Theory underlines the need for an orderly social organization that is built into a structure with an organizational leader. The elected leader, however, has a written or unwritten arrangement with the society that he represents. The customary communities in various ethnic groups in Indonesia are also systemically characterized by the presence of a leader, known as a local leader with various roles and privileges. Avessina's noted [16] that local leaders have an essential role in three social aspects, namely cultural ownership and natural resources, agents of cultural change in community service programs, and as social sanctions authorities in society. Local leaders are determined within the local community with various agreed criteria, either written or unwritten. Local leaders are usually decided by lineage and passed down from one generation to the next. This situation exists in various ethnic group leaderships around the world.

In order to reinforce their presence, the early emergence of local leaders is also connected to different aspects of mythology that are believed and become guidance for life among the community. The local leaders were, along with their beliefs, genealogically associated with the highest gods. Whatever actions were taken by local leaders are viewed as a reflection of the decision-making authority, they have sacred and absolute powers [16].

Based on Orinbao [6] Mosalaki is the local leadership authority that is referred to as customary functionaries, a type of collegial government based on 
deliberation that agrees within the Lio ethnic group. Traditionally they have notable dominance in the ethnic area they lead. From social aspect, Mosalaki is understood as a group of local leaders who have social and cultural authority over natural resources. As a customary collegial functionary, Mosalaki's authority of power departs from the values passed down by the ancestors which include the history of ancestral migration, alliances and wars, as well as past power conflicts, battles between clan groups and so on [16].

Mosalaki's political role is very significant in the traditional life of the Lio people in Sikka Regency. Mr Y (67) in Paga Subdistrict, West Region of Sikka Regency, is a retired teacher and also a Mosalaki in his customary land. $\mathrm{Mr} \mathrm{Y}$ has the power to regulate the best time to plant, harvest, to hold a traditional ceremony, a wedding, followed by the determination of the belis/dowry, and how to resolve conflicts with customary procedures that persist to this day. As stated by Mr. Y, that customary settlement with local values is more obeyed and more feared by using various customary mantras which are still believed to be true until now:

"suatu saat ada peristiwa kehilangan sepeda motor, ada pemuda Lio diserahkan ke kantor polisi. Diinterograsi oleh polisi tidak ditemukan hasil, lalu polisi menghubungi saya. Esoknya saya undang pemuda itu ke rumah adat dan datang dengan diantar keluarganya, sambil menangis tersedu-sedu dan saya cukup memandang saja, pemuda itu langsung mengakudan minta maaf. Pada situasi ini berlaku hukum adat dengan upacara adat, dan yang salah tetap bersalah serta bertanggung jaab untuk mengembalikan. Masalah selesai “"

"One day, there was an incident motorcycle theft. The suspect was a young man from Lio, and he was handed over to the police station. There were no results from the interrogation by the police, so the police contacted me. The next day I invited the young man to the traditional house, and he came accompanied by his family. He wept as I watched him. The young man immediately confessed his action and apologized. In this situation, customary law with traditional regulation applies, and the wrongdoer is still guilty and has the responsibility to return the stolen item. Then, the problem is finished."

The obedience of the Lio people to Mosalaki was also carried over by the magic power possessed by the Mosalaki as direct descendants of their ancestors. Magi is believed to be a supernatural power that one wants to have without rational work on the part of humans to control the forces of nature in mysterious ways which are also called offerings. The offering to the God of Heaven is called Paa Ka Wula Leja, the offering to the earth soul is called Paa Ka Tana Watu. The Lio ethnic traditional house is called Riabewa, which is following its Mosalaki leadership area and is used as a centre for the activities of the Lio ethnic group. The traditional house of the Lio ethnic group is also called Sao Ria, or Lepa Ria in the Paga language. The house is a stilt building with a roof extending from the top to the wall, without a window [3]. The house is built from the region's typical grass. In general, ethnic traditional housing in Lio still retain local customary values [17]. One of the roles of a traditional house is to address issues that occur in the ethnic group through deliberation. Informant Y declared:

"seseorang yang punya salah, bila dibawa ke rumah adat dan bertemu denga Mosalaki, umumnya mereka sudah memiliki rasa bersalah dan secara otomatis akan menyatakan pengakuan dan meminta maaf atas kesalahan yang diperbuat. Selanjutnya masalah diselesaikan dengan acara adat, misalnya dengan membayar denda yang berupa makan bersama dengan seluruh warga. Situasi kebersamaan ini mempercepat selesainya suatu masalah".

"A person who makes a mistake is brought to a traditional house and meets Mosalaki. Generally, they already have a sense of guilt and will automatically confess and apologize for the wrongdoing. Furthermore, the problem is resolved in traditional events. One example is paying a fine in the form of preparing meals to eat together with all residents. The togetherness in this situation speeds up the resolution of a problem". 
Picture 2: Traditional house of Lio ethnic and its inside interior.
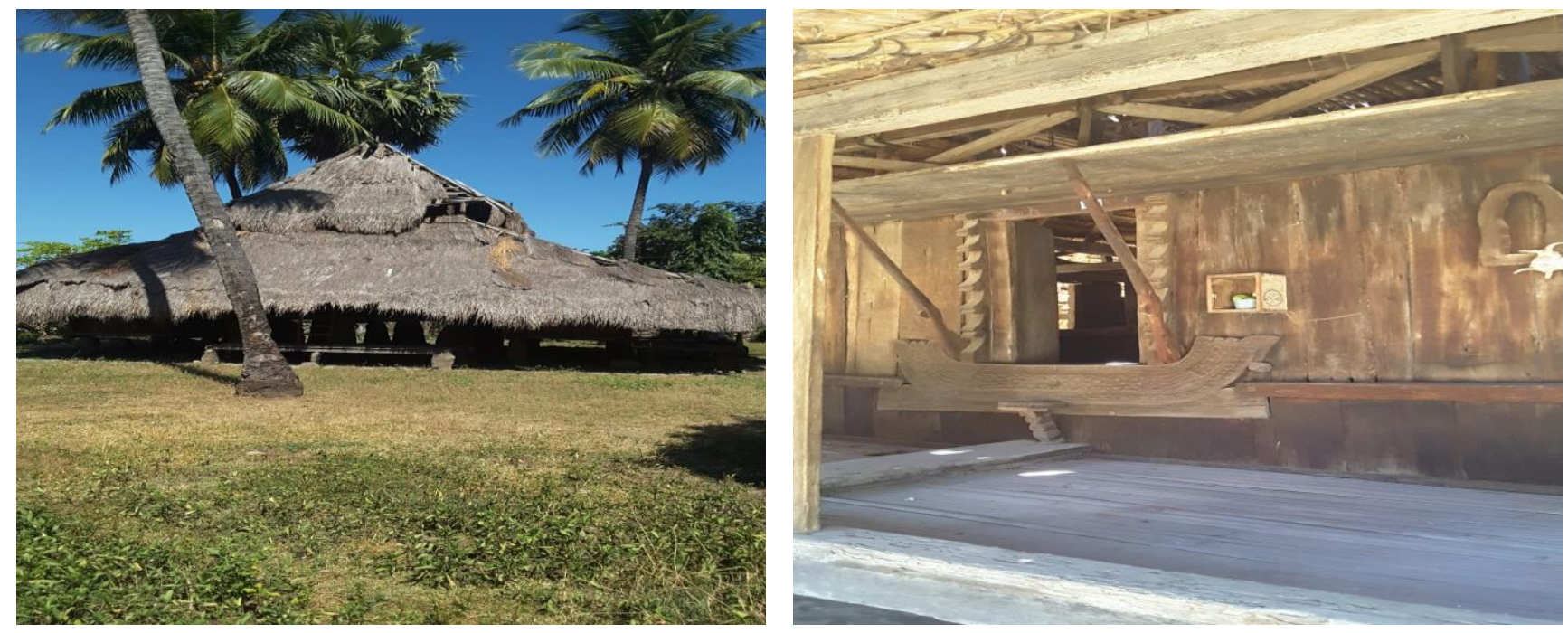

Research Documentation 2019.

The power relationship between Mosalaki and the customary people within the ethnic he leads is presented in the following actions: 1) the community obedience and respects for Mosalaki's instructions in expressing gratitude to the Almighty High, following advice on farming procedures, knowledge of seasons and natural cycles, prohibiting logging or natural destruction, and any other advices and instructions 2) there is a tradition of "upeti" in the form of community offerings to the Mosalaki for every harvest or crop [16].

In the structure of a feudal agrarian society like the Lio ethnic group in Sikka, the Mosalaki are the ruling class that owns the land and receives benefits from this ownership. On the other hand, they develop a legitimate ideology that is entirely used to convince the people of the right to rule. The greater the psychological commitment of the people to the Mosalaki, the less likely it is to rebel against the power they have. In the theory of ideology, legitimacy takes various forms, with the most common tactic for state rulers is to justify their government through religion while emphasizing supernatural sanctions against those who deviate from the social order in society [9]. In this theory, the existence of a Mosalaki is personified as the ruler of the state. Their advice and actions are and always followed/obeyed as an undeniable word.

\subsection{The Essential Role of Mosalaki in the Traditional Leadership System of the Lio Ethnic Group}

Customary governance in the leadership structure of the Lio Ethnic in Sikka Regency is a further illustration of the Lio Ethnic leadership in Ende Regency. Customary governance consists of a laki ria council, namely seven collegial leadership structures, and Laki $P u^{\prime} u$ as the top member of the Laki Ria council. Based on the instructions of Laki Ria, originating from Laki $P u^{\prime} u$, Ria Bewa has a position as the regulator, executive and organizer. Laki $P u^{\prime} u$ has jurisdiction and is the highest status over religious institutions and has special rights such as tedu mulu, namely the right to plant first, and keti mulu, namely the right to reap first. Ria Bewa mainly deals with the fellowship of the land. Laki Ria that is responsible for the safety of the people in the land of the fellowship called Laki Su'u. Male Wanga, which means to hold above the head, and carry on the shoulders, is a picture of the structure of Mosalaki leadership in Lio Ethnic. In seven functions, Olaf Smedal [16] proposes the Mosalaki group as follows:

1. Mosa Kaba Laki Wea is a Mosalaki who has a role is to control the yield of food resources, gold, and animals

2. Mosa Tana Laki Watu atau Mosa Watu laki Tana is a Mosalaki who has the authority to use the land. 
3. Mosa Nua Laki bo'a is a Mosalaki who is in charge of village maintenance

4. Mosa Wiwi Laki Wela is a Mosalaki who plays a role in conveying social messages, values and virtues

5. Mosa Toa Laki Wela is a Mosalaki who deals with the religious aspect

6. Mosa Pedu Laki Rona/ Mosa Peu Laki Rona/ Mosa Wiu Laki Pi'u/ Mosa Pedu Laki Pada is a Mosalaki who plays a role in determining and passing on regulations/advice/oral traditions

7. Mosa Po Laki Pera is a Mosalaki who has the authority as a political leader and can rule other Mosalaki.

Observing this categorization, Mosalaki's position in the Lio Ethnic community system describes an organized and well-structured community organization. There is a division of duties and authorities in the unifying collegial principle. They perform their duties in accordance with their respective roles, which are implied in the fields of natural resource products management and storage, customary land ownership and maintenance, village accountability, social responsibility, religious responsibility, guidance in the realization of oral traditions and politics [16]. Within the ethnic community, oral traditions articulate their duties and responsibilities, which have a lot to do with virtuous ideals of respecting others the environment, and so on. This condition has also become a distinctive tradition for the Palue ethnic group in the northern part of Sikka Regency at the foot of Mount Rokatenda. They recognize that oral traditions include many principles to protect the surrounding environment, which sometimes in contrast with modern development [18]. In other Lio ethnic groups, the highest customary chief in this place is called Ria Bewa, and at a lower level, they have mosalaki, bogahage, bogeria to bogelo $o$ as guardians of traditional activities. The traditional ties to the Lio ethnic group everywhere, including those in Sikka Regency, are powerful, especially those related to respect for the Highest Almighty and respect for nature.

On another aspect, [19] explained the legitimacy of the power that Mosalaki has on the Lio ethnicity are as follows:

1) A certain Mosalaki has the right to lead and to run a clan-controlled communal territory. He has the right to inherit the land from the patrilineal lineage to ana darinia, which is a member of the clan, considering the cultivated land (watas) of anakulo fa'e walu.

2) The right and authority to determine customary fines in the event of regular violations, which is carried out by Mosalaki Ria Bewa
3) The right and authority to lead rituals of respect for the common ancestors of ana darinia in the respective Mosalaki $\mathrm{Sa}^{\prime} \mathrm{o}$

4) The rights, authority and higher social status

5) The rights and obligations to lead and carry out traditional rituals, especially those related to farming schedules and ceremonies to honour ancestors.

6) Have full legitimacy to his children and offspring

7) The authority to regulate aspects of community life related to values in the Lio ethnic ideology.

The various forms of Mosalaki authority are actualized in the daily life of the Lio ethnic group.

\subsection{The Contemporary Role of Mosalaki in the Lio Ethnic Group in Sika Regency}

A hallmark of patriarchal ideology is the social structure that positions men as holders of power/leadership [20]. In this context, Talcot Parsons' functional structural theory [21], explained that a good community life system supports each other towards a dynamic balance. The balance in a patriarchal society is when men are the holders of leadership and powers that are recognized without maintaining them in the society in which they reside. Likewise, in the social system in the Lio ethnic in Sikka Regency places Mosalaki as a collegial leadership pattern which is held by male lineages. The social relations in the community, which he leads are patron clients. Therefore, with all his authority, a Mosalaki is often involved by the government to the extensions of governmental programs. For example, in the family planning program, transmigration, compulsory education, health program and et cetera. Globalization has changed many social structures in living their lives [22], which is related to a broader and more global network of interactions. This condition as stated [23] "the state does not monopolize the public sphere," and are seeking, as we are, ways to describe the sphere of international interactions under a variety of names: transnational relation, international civil society, and global civil society. The ultimate holder of authority is no longer the central government. The changes in Indonesian democratic politics in 1998 also affected the role of traditional leadership in Indonesia in several ethnic groups, as mentioned below:

Traditional power in modern political activities constantly incites the attention of scientists. This is due to the extensiveness of power legitimacy in traditional society which is often abused by power holders and utilized for political interests. In the contemporary context, the use of traditional power is often linked to activities of General Election (Pemilihan Umum Pemilu) or Regional Election (Pemilihan Kepala Daerah - Pilkada) by involving the masses [24]. 
The position of Mosalaki, which has been connected to local customary issues so far, is becoming increasingly widespread in the political arena, especially in the regional head-up elections. The Mosalaki's charisma became an extension of the candidate to spread power and obtain support for their electability. One of the Lio ethnic Mosalaki, in Paga stated "that this is a tough challenge for the customary duties he is responsible for, because a Mosalaki must side with the welfare of the indigenous people he leads as a whole and should not be influenced for certain interests". This is a tough challenge for the customary people he is responsible for, because a Mosalaki must side with the welfare of the people he leads as a whole and should not be compromised by certain interests. Today, due to the increasingly high demands of global life, the function and place of Mosalaki is increasingly difficult, especially when natural products are not always a secure source of livelihood. A Mosalaki is always described as a rich person and is always ready to pay for various needs for traditional ceremonies. This condition has, for some time been contrary to reality, related to Mosalaki's financial strength and ability. Therefore, along with the times and the birth of different types of new values in custom and leadership in the Lio ethnic community in Sikka Regency, the power and centralism of Mosalaki's leadership in the Lio Ethnic custom is directly and indirectly decreasing. However, the values of respect for leaders, elders, and various other forms of customary respect are the values of local wisdom that cannot be eroded by globalization. For the local community, the presence of Mosalaki with all his abilities remains a role model, particularly with the values of wisdom they possess.

\section{CONCLUSION}

Mosalaki is the traditional leader of the Lio ethnic group in Ende and Sikka districts. Mosalaki is a logar leadership model. It is collegial in the Lio ethnic group that consists of various leadership elements tied into one system. Mythologically they are direct descendants of their ancestors, male, and have full authority to provide direction and manage all sources of life in the community they lead. Mosalaki is a charismatic figure because he has genealogical ancestry to the ancestors and mastery of customary regulations. The words and actions by Mosalaki are full of advice and obligation that can be disastrous if violated. Globalization presents ideas of change related to the position and role of Mosalaki in the Lio ethnic group in today's modern life, namely the participation of Mosalaki in socializing development policies both at the local and national levels.

\section{ACKNOWLEDGMENT}

Acknowledgement for the Director of Research and Community Service of the Ministry of Research and Technology/National Agency for Research and Innovation of the Republic of Indonesia for providing opportunities and funding to the author through the DRPM Research Grant program with grants number 25/ E1/KPT/2020.

\section{REFERENCES}

[1] E. Junaedi, "Mengungkap Harmoni Umat Islam di Kantong Mayoritas Kristen Nusa Tenggara Timur (NTT)," Harmoni, vol. 15, no. 3, pp. 173-180, 2016.

[2] K. G. dan Y. Rante, "Manajemen Konflik Atasi Dampak Masyarakat Multikultural Indonesia," Mitra Ekonomi dan Manajemen Bisnis, vol. 2, no. 2, pp. 212-224, 2011.

[3] Suswandari and S. Astuti, "Kearifan Lokal Dalam Keragaman Etnik di Kabupaten Sikka," 2020.

[4] S. A. and Suswandari, "Ethnic Diversity In Sikka Regency East Nusa Tenggara as A Principle of Multikulturalism," International Journal of Advanced Science and Technology, vol. 29, no. 6, pp. 4711-4720, 2020.

[5] M. A. Krivo, "Lio dan Asal Muasal," 2014. http://animasisoetts.blogspot.com/2014/09/liodan-asal-muasal.html.

[6] P. S. Orinbao, Tata berladang tradisional dan pertanian rasional suku-bangsa Lio. Seminari Tinggi St. Paulus, Ledalero, 1992.

[7] Suswandari, S. Astuti, and E. N. Susanti, "Local Wisdom Of Tana Ai Ethnic As An Effort To Preserve Harmonious And Sustainable Environment In Ojang Village, Talibura Distric, Sikka Regency, East Nusa Tenggara," Jour of Adv Research in Dynamical \&Control Systems, vol. 12, no. 06, pp. 2364-2376, 2020, doi: 10.5373/JARDCS/VI216/S20201196.

[8] I. Mboka, "Penggunaan Doa Batuna'U Dalam Tradisi Etnik Lio di Desa Ngalukoja Kecamatan Maurole Kabupaten Ende: sebuah Kajian Linguistik Kebudayaan," Paradigma Jurnal Kajian Kebudayaan Fakultas Ilmu Pengetahuan Budaya Universitas Indonesia, vol. 6, no. 2, pp. 156-177, 2016.

[9] S. P. Syahrie, "Jalinan Feodalisme dan Kapitalisme Agraris: Telaah Terhadap Buku kebesaran dan Tragedi Kota Banten," Jurnal Sejarah Lontar, vol. 4, no. 2, 2007.

[10] J. P. Spradley, Metode Etnografi. Yogyakarta: Tiara Wacana, 1997. 
[11] J. D. Brewer, Ethnography. Buckingham: Open University Press, 2000.

[12] R. Bogdan and S. K. Biklen, Qualitative Research for Education. Boston: Allyn \& Bacon Boston, MA, 1997.

[13] Suwarno, "Pemanfaatan Majalah Suara Muhammadiyah Edisi 2015 sebagai Sumber Belajar Dinamika Peradaban Islam," TSAQAFAH, vol. 15, no. 1, pp. 119-136, 2019.

[14] Windiani and F. N. R, "Menggunakan Metode Etnografi dalam Penelitian Sosial," Dimensi Jurnal Sosiologi, vol. 9, no. 2, pp. 87-92, 2016.

[15] W. W. Isajiw, "Definition and dimensions of ethnicity: A theoretical framework," Challenges of measuring an ethnic world: Science, politics and reality, pp. 407-427, 1993.

[16] M. J. Avessinna, "Perubahan dan Kontinuitas: Peran Pemimpin Lokal Dalam Penguasaan Sumber daya Air Kolektif Pada Masyarakat Maukaro Ende," Neraca Keuangan Jurnal Ilmiah akuntansi, vol. 11, no. 1, 2016.

[17] M. A. Mukhtar, G. W. Pangarsa, and L. D. Wulandari, "Struktur Konstruksi Arsitektur Tradisional Bangunan Tradisional Keda Suku Ende Lio di Permukiman Adat Wolotolo," Ruas, vol. 11, no. 1, 2013.
[18] S. Danerek, "Peran Warisan Lisan dan Komunitas Adat palu'e Dalam Perlindungan Alam," 2014.

[19] J. E. M. Prioharyono, "Kekuasaan Politik dan Adat Para Mosalaki di Desa Nggela dan Tenda, Kabupaten Ende, Flores," Antropologi Indonesia, vol. 33, no. 3, pp. 180-201, 2012.

[20] Suswandari and T. Corliana, Resistensi Perempuan Terhadap Praktik Ideologi Patriarkhi: suatu Tinjauan Sejarah Sosial. Jakarta: Ghaniya Publisher, 2013.

[21] T. Parsons, The Present Status of "StructuralFunctional" Theory in Sociology." In Talcott Parsons, Social Systems and The Evolution of Action Theory. New York: The Free Press, 1975.

[22] A. Giddens, "The Third Way: The Renewal of Social Democracy. Jakarta: PT SUN, 2002.

[23] M. E. K. and K. Sikkink, "Transnational Advocacy Netwoks In International Politic 1998," in The Globalization and Development Reader Perspectives on Development and Global Change Second Edition, 2nd ed., J. T. S. R. A. B. H. N. Chore, Ed. West Sussex: John Willey and Sons, 2015, p. 476.

[24] Asrinaldi, "Power Network of Penghulu Adat in The Concurrent Regional Election in West Sumatera," Jurnal Ilmu Sosial dan Politik, vol. 21, no. 1, pp. 57-73, 2017 